\title{
Kinetic, thermodynamic properties, and optimization of barley hydration
}

\author{
Flávia Daiana MONTANUCI ${ }^{1}$, Luiz Mario de Matos JORGE², Regina Maria Matos JORGE ${ }^{1 *}$
}

\begin{abstract}
The hydration kinetics of five barley cultivars was studied at six different temperatures ranging from 10 to $35^{\circ} \mathrm{C}$ for 32 hours applying the Peleg model. Response Surface was used to describe dynamic of the process and identify the hydration time for each cultivar. The activation energy $\left(\mathrm{E}_{\mathrm{a}}\right)$, enthalpy $\left(\Delta \mathrm{H}^{*}\right)$, entropy $\left(\Delta \mathrm{S}^{*}\right)$, and Gibbs free energy $\left(\Delta \mathrm{G}^{*}\right)$ were estimated from the adjusted parameters and Arrhenius equation. Temperature had significant effect on the hydration of the five cultivars. At low temperatures, the stabilization time for hydration was faster. Peleg constants $\mathrm{K}_{1}$ and $\mathrm{K}_{2}$ decreased with increasing temperature. The cultivar BRS BRAU showed the lowest value of initial absorption rate $\left(\mathrm{R}_{0}=0.149 \mathrm{~kg} \cdot \mathrm{h}^{-1}\right)$ at $10^{\circ} \mathrm{C}$, while the cultivar BRS BOREMA had the highest value of $R_{0}\left(0.367 \mathrm{~kg} \cdot \mathrm{h}^{-1}\right.$ at $\left.35^{\circ} \mathrm{C}\right)$. The equilibrium moisture content $\left(\mathrm{M}_{\mathrm{e}}\right)$ increased with increasing temperature. The cultivars BRS CAUE and BRS BRAU showed the lowest values of $\mathrm{E}_{\mathrm{a}}, \Delta \mathrm{H}^{*}, \Delta \mathrm{S}^{*}$ showed negative values, and $\Delta \mathrm{G}^{*}$ increased with increasing temperature, confirming the effect of temperature on hydration.
\end{abstract}

Keywords: transport phenomena; hydration isotherm; thermodynamic properties; absorption; kinetics; barley.

\section{Introduction}

Barley (Hordeumvulgare L.) is a cereal belonging to the grass family and the genus Hordeum (FOOD..., 2007). It is considered a functional grain as it is a source of $\beta$-glucan, complex B vitamins, tocopherols, and tocotrienols, which are known to reduce serum LDL cholesterol by their antioxidant activity (BAIK; ULLRICH, 2008; SHARMA; GUJRAL; ROSELL, 2011).

One of the steps in the production of malt is barley hydration. In the steeping process, the grain is soaked in water for 24 to 36 hours in order to increase its moisture to $42-44 \%$ (wet basis). Water uptake by the grain may be influenced by factors such as barley composition, grain structure, water temperature during steeping, and steeping method. After steeping, the grains are removed from water for the germination step under controlled temperature and moisture for several days. The next step is grain drying (BARREIRO; FERNÁNDEZ; SANDOVAL, 2003; MAYOLLE et al., 2012).

Steeping or hydration plays a crucial role in the determination of the final malt quality and, accordingly, detailed knowledge of water uptake in barley kernels is important in order to optimize the malting process (GRUWEL et al., 2001). Hydration of cereals and leguminous plants is important in the preparation of such products because it improves palatability, denatures proteins, and at some temperatures it causes previous gelatinization of starch, besides facilitating the cooking or germination steps. From the point of view of process engineering, it is important to understand the dynamics of water absorption, or sorption, and to identify the influence of process variables on the product. Thus, quantitative measurements of the effect of hydration are necessary for practical applications aimed at the design and optimization of industrial processes (HSU, 1983a, b; SOPADE; AJISEGIRI; BADAU, 1992; MASKAN, 2001, 2002).

Kinetic models of grain hydration have been developed with the purpose of estimating the time required to obtain desired moisture content at a given temperature or to predict the dynamic behavior of the soaking process, or as a design tool for equipment sizing. The models developed to represent the dynamic behavior of the hydration or soaking process are basically of two types: empirical and phenolmenological (PELEG, 1988; SOPADE; OBEKPA, 1990; ABU-GHANNAM; MCKENNA, 1997; MASKAN, 2002; RESIO; AGUERRE; SUAREZ, 2006; OMOTO et al., 2009; COUTINHO et al., 2005, 2007; OULAHNA et al., 2012). Peleg model (PELEG, 1988) has been the most widely used empirical model in recent years to model the behavior of different grains and food products during hydration.

Sorption isotherms and isosteric heat of sorption of cereal based products are also essential for the design, modelling, and optimization of many processes. Applying thermodynamic functions is possible to provide information about the affinity between water and the cereal product including the binding forces, the water molecules, their spatial arrangement, and the spontaneity of the sorption process (OULAHNA et al., 2012).

The objective of this study was to evaluate the kinetic hydration process of five different barley cultivars, find the optimal hydration period of time for each cultivar, and apply the Peleg model to estimate the following thermodynamic properties: activation energy $\left(\mathrm{E}_{\mathrm{a}}\right)$, enthalpy $\left(\Delta \mathrm{H}^{*}\right)$, entropy $\left(\Delta S^{\star}\right)$, and Gibbs free energy $\left(\Delta \mathrm{G}^{\star}\right)$.

\footnotetext{
Received 6/6/2013

Accepted 9/3/2013 (006098)

1 Programa de Pós-Graduação em Engenharia de Alimentos, Centro Politécnico, Setor de Tecnologia, Universidade Federal do Paraná - UFPR, Jardim das Américas,

CEP 81531-980,Curitiba, PR, Brasil, e-mail: reginacspr@yahoo.com.br

2 Departamento de Engenharia Química, Universidade Estadual de Maringá - UEM, Maringá, PR, Brasil

${ }^{*}$ Corresponding author
} 


\section{Materials and methods}

\subsection{Material}

Five barley cultivars grown in southern Brazil (2011 harvest), were used to study barley hydration. BRS BRAU, BRS CAUE, BRS BOREMA, BRS 195, and BRS GRETA, are cultivars registered by EMBRAPA (Brazilian Agricultural Research Corporation) and were donated by the Agroindustrial Cooperative from Paraná state and Embrapa Wheat from Rio Grande do Sul in Brazil. All samples were stored under refrigeration at $5^{\circ} \mathrm{C}$.

\subsection{Chemical composition of barley grains}

The chemical composition of barley grains was determined according to the of the Association of Official Analytical Chemists official method (ASSOCIATION..., 1995). Moisture was determined by drying the sample in oven at $105^{\circ} \mathrm{C}$. Protein was determined using the Kjeldahl method with conversion factor of 6.25, lipids by the Soxhlet extraction method; ash content by incineration at $550{ }^{\circ} \mathrm{C}$ in muffle furnace, starch by acid hydrolysis and polarimeter reading (Polax WXG-4), and dietary fiber by the enzymatic method. Statistical analysis was performed using ANOVA followed by the Tukey test for pairwise comparisons of means, at significance level of $5 \%$.

\subsection{Hydration process}

Assays were performed in a Dubnoff shaker water bath with controlled temperature (Q226M2 Quimis). In each experiment, $250 \mathrm{~g}$ of barley grains were immersed in distilled water. The experiments were performed in duplicate for each hydration temperature, collecting samples in duplicate so that four samples were obtained at each sampling time.

The temperatures $\left({ }^{\circ} \mathrm{C}\right)$ for the tests were: $10,15,20,25,30$, and 35 , with total hydration time of 32 hours. Grain samples were taken after the following times (hours): $0,0.08,0.5,1,1.5$, $2,2.5,3,3.5,4,5,6,7,8,10,12,14,16,18,20,22,24,26,28,30$, and 32 . Excess surface water was removed from the sampled grains with paper towels.

The dry basis moisture content was evaluated using Equation 1, where $\mathrm{M}=$ moisture (\% dry basis) is expressed by the ratio between the mass of water present in the sample $\left(M_{w}\right)$, calculated after drying at $105^{\circ} \mathrm{C}$ for $24 \mathrm{~h}$, and the mass of dry sample $\left(M_{d}\right)$ (ASSOCIATION..., 1995).

$\mathrm{M}=\left(\mathrm{M}_{\mathrm{w}} / \mathrm{M}_{\mathrm{d}}\right) \times 100$

The values of moisture (dry basis) were used to fit a polynomial equation that can be presented in a graphical form of Response Surface for moisture estimate of each cultivar, as a function of temperature and time. From the polynomial equation obtained for each cultivar, the period of time that provides the maximum moisture on a dry basis was estimated. Results were statistically analyzed by ANOVA at the significance level of $5 \%$.
The Peleg model was fitted to the experimental results, which is represented by Equation 2, where $M(t)=$ moisture as a function of time ( $\mathrm{t}$ ) (\% dry basis); $\mathrm{M}_{0}=$ initial moisture ( $\%$ dry basis); $\mathrm{t}=$ soaking time $(\mathrm{h}), \mathrm{K}_{1}=$ Peleg rate constant $\left(\mathrm{h} \%{ }^{-1}\right)$; and $\mathrm{K}_{2=}$ Peleg capacity constant $\left(\%^{-1}\right) . \mathrm{K}_{1}$ is related to the rate of water absorption and $\mathrm{K}_{2}$ to the equilibrium moisture (PELEG, 1988).

$M(t)=M_{0} \pm t /\left(K_{1}+\left(K_{2} \times t\right)\right)$

In Equation 2, ' \pm ' becomes ' + ' if the process is absorption or adsorption and '-' if the process is drying or desorption. The rate of sorption $(\mathrm{R})$ can be obtained by the first derivate of Peleg equation, Equation 3:

$\mathrm{R}=\mathrm{dM}(\mathrm{t}) / \mathrm{dt}= \pm \mathrm{K}_{1} /\left(\mathrm{K}_{1}+\mathrm{K}_{2} \times \mathrm{t}\right)$

The Peleg rate constant $K_{1}$ is inversely related to initial water rate sorption rate at the very beginning $\left(R_{0}\right)$, i.e. $R$ at $t=t_{0}$ (Equation 4).

$\mathrm{R}_{0}=\mathrm{dM} /\left.\mathrm{dt}\right|_{10}= \pm 1 / \mathrm{K}_{1}$

The Peleg capacity constant $\mathrm{K}_{2}$ relates to maximum (or minimum) attainable moisture content. As $\mathrm{t} \rightarrow \infty$, Equation 2 gives the relation between equilibrium moisture content $\left(\mathrm{M}_{\mathrm{e}}\right)$ (\% dry basis) and $\mathrm{K}_{2}$ (Equation 5):

$\mathrm{M} \mid \mathrm{t}_{\infty}=\mathrm{M}_{\mathrm{e}}=\mathrm{M}_{0} \pm 1 / \mathrm{K}_{2}$

Linearization of Equation 2 yields Equation 6.

$\mathrm{t} /\left(\mathrm{M}(\mathrm{t})-\mathrm{M}_{0}\right)=\mathrm{K}_{1}+\mathrm{K}_{2} \mathrm{t}$

A plot of $t /\left(M(t)-M_{0}\right)$ against time, $t$, gives a straight line with $\mathrm{K}_{1}$ as the ordinate intercept and $\mathrm{K}_{2}$ as the gradient of the line.

Sopade, Ajisegiri and Badau, 1992 reported that $\mathrm{K}_{1}$ could be likened to a diffusion coefficient and Arrhenius equation could be used to describe the influence of temperature on constant $\mathrm{K}_{1}$ (Equation 7).

$1 / \mathrm{K}_{1}=\mathrm{K}_{\mathrm{ref}} \exp \left[\left(-\mathrm{E}_{\mathrm{a}} / \mathrm{R}\right) \times\left(1 / \mathrm{T}-1 / \mathrm{T}_{\mathrm{ref}}\right)\right]$

The linearization of Equation 7 yields Equation 8, from which activation energy value can be calculated (Equation 8).

$\operatorname{Ln}\left(1 / \mathrm{K}_{1}\right)=\left[\operatorname{Ln~} \mathrm{K}_{\mathrm{ref}}+\left(-\mathrm{E}_{\mathrm{a}} / \mathrm{R}\right)\left(-1 / \mathrm{T}_{\mathrm{ref}}\right)+\left(-\mathrm{E}_{\mathrm{a}} / \mathrm{R}\right)(1 / \mathrm{T})\right]$

In these equations, $\mathrm{K}_{\text {ref }}$ refers to the hydration constant at a reference temperature $\mathrm{T}_{\text {ref }}, \mathrm{E}_{\mathrm{a}}$ is the activation energy, $\mathrm{R}$ is the universal gas constant, and $\mathrm{T}$ is the hydration temperature. According to Gowen et al. (2007) and Jideani and Mpotokwana (2009), the reference temperature is the average of the temperatures used for hydration. In the present study, $\mathrm{T}_{\text {ref }}$ is $22.5^{\circ} \mathrm{C}$.

When $\ln \left(1 / \mathrm{K}_{1}\right)$ is plotted against $(1 / \mathrm{T})$, a straight line with slope $\left(-\mathrm{E}_{\mathrm{a}} / \mathrm{R}\right)$ is obtained, from which the activation energy can be calculated and sensitivity of the constant to the temperature can be assessed. 


\subsection{Solids loss (\%)}

The content of soluble solids released from barley was estimated as the amount of solids present in the water drained, expressed as the percentage reduction of barley dry weight compared to the initial percentage (MASKAN, 2001).

\subsection{Thermodynamic considerations}

The values of $\mathrm{E}_{\mathrm{a}}$ allow the determination of different thermodynamic parameters such as enthalpy $\left(\Delta \mathrm{H}^{*}\right)$, entropy $\left(\Delta \mathrm{S}^{*}\right)$, and Gibbs free energy $\left(\Delta \mathrm{G}^{*}\right)$ according to Equations 9 , 10 , and 11 initially proposed by Sánchez et al. (1992) and applied by Jideani et al. (2002) and Jideani and Mpotokwana (2009).

$$
\begin{aligned}
& \Delta \mathrm{H}^{*}=\mathrm{E}_{\mathrm{a}}-\mathrm{RT} \\
& \Delta \mathrm{S}^{*}=\mathrm{R}\left(\ln \mathrm{K}_{\mathrm{ref}}-\ln \left(\mathrm{K}_{\mathrm{b}} / \mathrm{h}_{\mathrm{p}}\right)-\ln \mathrm{T}\right) \\
& \Delta \mathrm{G}^{*}=\Delta \mathrm{H}^{*}-\mathrm{T} \Delta \mathrm{S}^{*}
\end{aligned}
$$

In these equations, $\mathrm{R}$ is the universal gas constant, $\ln \mathrm{K}_{\mathrm{ref}}$ is the ordinate intersection of the line obtained by linear regression to calculate Ea, $\mathrm{K}_{\mathrm{b}}$ is Boltzmann's constant $\left(1.38 \times 10^{-23} \mathrm{~J} . \mathrm{K}^{-1}\right)$, $h_{p}$ is Planck's constant $\left(6.626 \times 10^{-34} \mathrm{~J} . s\right)$, and $\mathrm{T}$ is the absolute temperature. Results were statistically analyzed by ANOVA at the significance level of $5 \%$.

\section{Results and discussion}

\subsection{Chemical composition of the barley cultivars}

Table 1 shows the chemical composition of the barley cultivars. The average values of lipids and starch content were $2.32 \%$ and $57.35 \%$, respectively, with no significant difference between the cultivars ( $p>0.05$ ). The initial moisture content ranged from 11.96 to $13.49 \%$. BRS 195 and BRS BRAU with the highest moisture contents and the lowest value was that of BRS CAUE. Protein content ranged from 9.55 to $10.56 \%$; BRS 195 and BRS BOREMA showed the highest values. As for ash content, the results ranged from 1.73 to $2.47 \%$; BRS 195 and BRS GRETA showed the highest levels, differing significantly ( $p \leq 0.05$ ) from the other cultivars. Values from 17.00 to $19.61 \%$ were found in the dietary fiber analysis, and BRS 195 and BRS GRETA showed the highest values. BRS CAUE showed an intermediate value, while the lowest levels were found for BRS BRAU and BRS BOREMA.

Studies by Aman and Newman (1987), Oscarsson et al. (1996), and Andersson et al. (1999), which are available in the literature, reported that barley grains are composed of $53-67 \%$ starch, $14-25 \%$ fiber, $9-14 \%$ protein, 3-4\% lipids, $2-3 \%$ ash, $1-7 \%$ low molecular weight carbohydrates, $4-11 \%$ arabinoxylans, $3-7 \%$ $\beta$-glucan, and small amounts of cellulose and lignin. On the other hand, Izydorczyk et al. (2000) and Quinde, Ullrich and Baik (2004) found higher starch content in barley grains, ranging from 65 to $68 \%$ and $10-17 \%$ protein, $11-34 \%$ fiber, and $4-9 \%$ $\beta$-glucan. The results obtained are consistent with the average values in the literature, taking into account that the chemical composition is influenced by the climate and soil of the region where the cultivars were grown.

\subsection{Hydration}

Figure 1 shows the evolution of hydration isotherms at different temperatures for the studied cultivars. The comparison of experimental means by statistical analysis applying the Tukey test indicated that the behaviour of hydration kinetics of the five cultivars was similar $(p>0.05)$. It can be observed that at all temperatures, water uptake was faster in the initial stages, especially in the first four hours, and gradually slowed down as the moisture content approached saturation. According to Hsu (1983a), it had been demonstrated that diffusion in the solid endosperm is the main mechanism that controls the rate of absorption in seeds regardless of the process conditions. There was a significant effect of temperature on the grain moisture ( $p$ $\leq 0.05$ ), mainly on the dynamic of hydration isotherms and also on the equilibrium moisture of the five cultivars.

It was observed that the higher the temperature, the greater the rate of water absorption in the hydration process, in accordance with Geankoplis (1983), who states that the rate of hydration increases with increasing temperature. This increase is due to changes in resistance to grain diffusion. Higher temperatures are known to expand and soften grains (KASHANINEJAD et al., 2007). Several studies have shown that increasing the temperature of the soaking medium is an excellent way to accelerate the water absorption of various seeds, reducing the soaking time (QUAST; DA SILVA, 1977; KON, 1979; SOPADE; OBEKPA, 1990; ABU-GHANNAM; MCKENNA, 1997; TANG; SOKHANSANJ; SOSULSKI, 1994; HUNG et al., 1993; SEYHAN-GÜRTAS; AK; EVRANUZ, 2001; HSU, 1983a; MASKAN, 2002). The moisture content of the grains during hydration can be directly related to two variables: time and temperature. As the hydration time is increased, the amount of water absorbed increases (WANG et al., 1979;

\begin{tabular}{|c|c|c|c|c|c|c|}
\hline Cultivar & Moisture content (\%) & Lipids (\%) & Protein $(\%)$ & Starch (\%) & Ash (\%) & Dietary fiber (\%) \\
\hline BRS CAUE & $11.96^{\mathrm{c}} \pm 0.54$ & $2.19^{\mathrm{a}} \pm 0.06$ & $9.64^{\mathrm{b}} \pm 0.06$ & $58.24^{\mathrm{a}} \pm 0.61$ & $1.73^{c} \pm 0.01$ & $18.90^{\mathrm{b}} \pm 0.00$ \\
\hline BRS BRAU & $13.49^{\mathrm{a}} \pm 0.21$ & $2.18^{\mathrm{a}} \pm 0.05$ & $9.62^{\mathrm{ab}} \pm 0.15$ & $56.58^{\mathrm{a}} \pm 0.61$ & $1.86^{c} \pm 0.04$ & $17.00^{c} \pm 0.01$ \\
\hline BRS BOREMA & $12.38^{b c} \pm 0.07$ & $2.49^{\mathrm{a}} \pm 0.32$ & $10.23^{\mathrm{a}} \pm 0.40$ & $56.77^{\mathrm{a}} \pm 0.61$ & $2.14^{\mathrm{b}} \pm 0.09$ & $17.94^{\mathrm{c}} \pm 0.00$ \\
\hline BRS 195 & $13.02^{\mathrm{ab}} \pm 0.02$ & $2.51^{\mathrm{a}} \pm 0.19$ & $10.56^{\mathrm{a}} \pm 0.19$ & $56.95^{\mathrm{a}} \pm 0.60$ & $2.43^{\mathrm{a}} \pm 0.04$ & $19.61^{\mathrm{a}} \pm 0.01$ \\
\hline BRS GRETA & $12.70^{\mathrm{b}} \pm 0.12$ & $2.39^{\mathrm{a}} \pm 0.28$ & $9.55^{\mathrm{ab}} \pm 0.09$ & $57.50^{\mathrm{a}} \pm 0.78$ & $2.47^{\mathrm{a}} \pm 0.08$ & $19.25^{\mathrm{a}} \pm 0.01$ \\
\hline
\end{tabular}
SOPADE; OBEKPA, 1990).

Table 1. Chemical composition of barley cultivars (Mean \pm standard deviation).

Values followed by the same symbol in each column do not differ significantly $(\mathrm{p} \leq 0.05)$. 


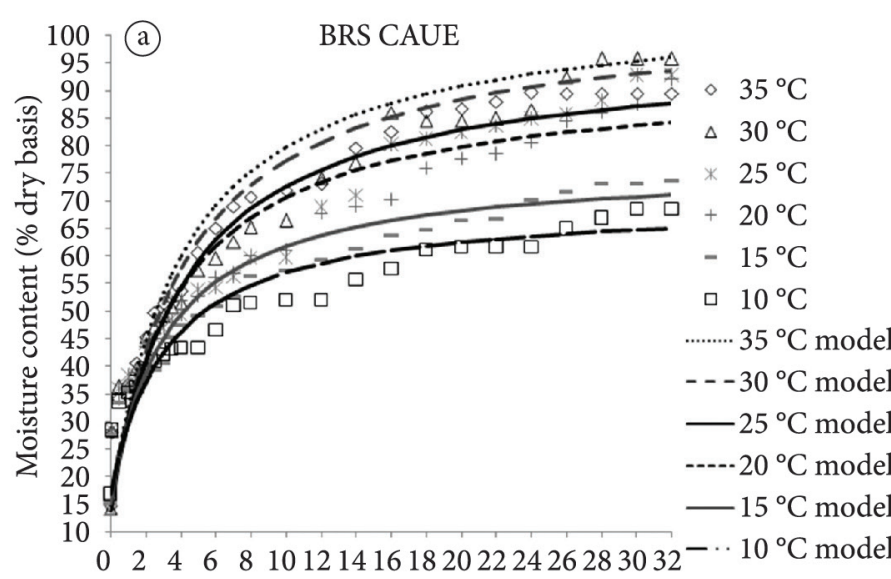

Time (h)

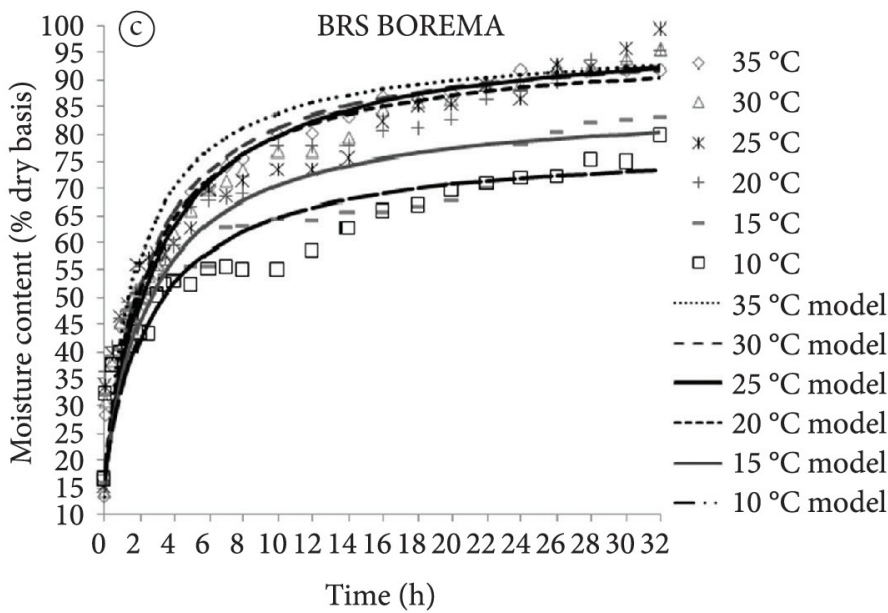

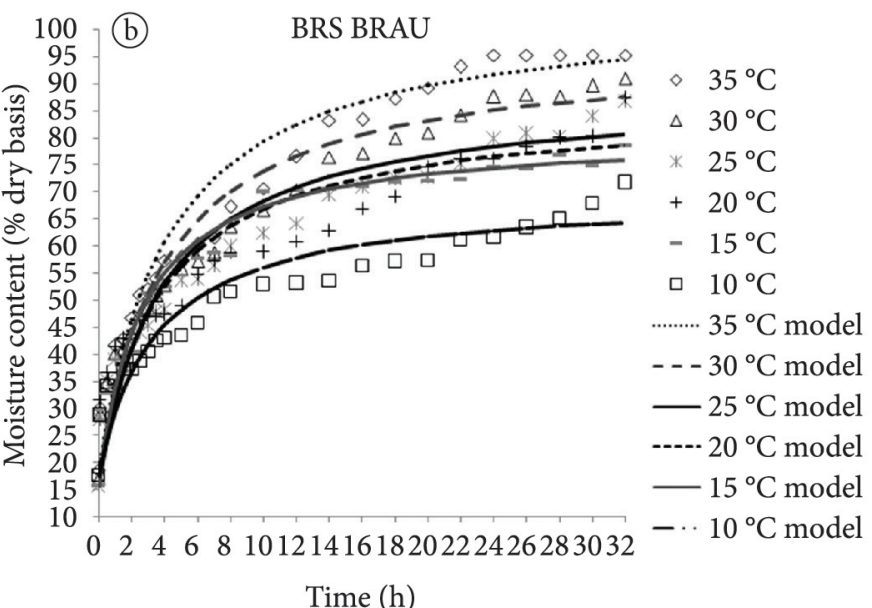

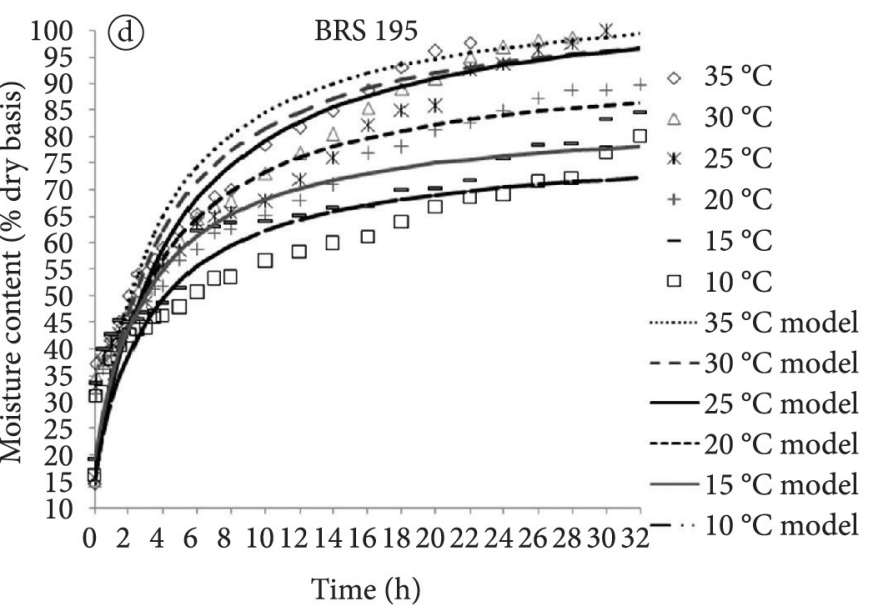

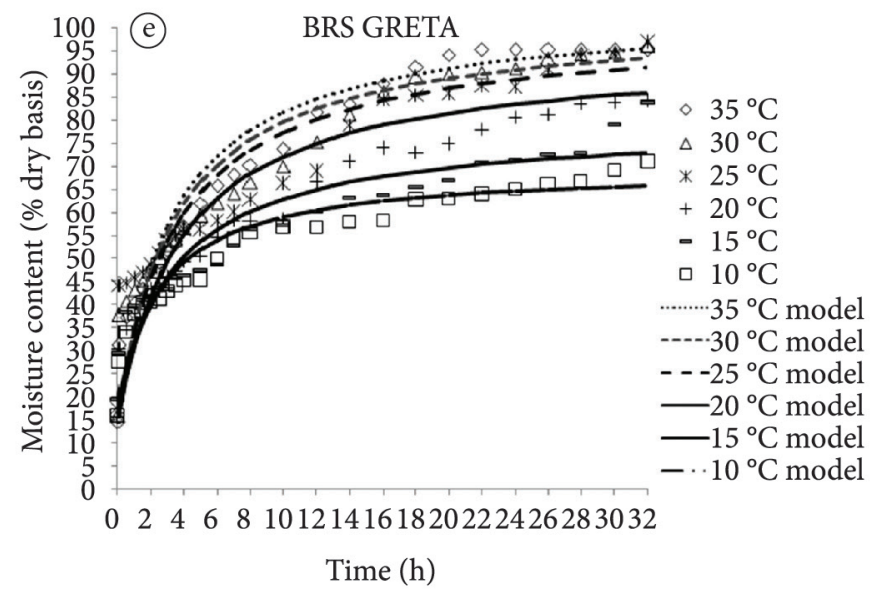

Figure 1. Experimental data and prediction of Peleg model for the hydration of the five barley cultivars at different temperatures between 10 and $35^{\circ} \mathrm{C}$, (A) BRS CAUE, (B) BRS BRAU, (C) BRS BOREMA, (D) BRS 195, and (E) BRS GRETA.

The kinetics of hydration determined the time required for stabilization of the moisture in the interior of the grain. It was observed that the higher the temperature, the longer the stabilization time required thus reaching 6 hours difference on average when comparing the temperature results obtained in the range of 10 to $35^{\circ} \mathrm{C}$.

Table 2 shows the equations generated for the Response Surface of moisture for each cultivar, and Table 3 shows the time in hours required for the grain to reach moisture equilibrium. This time was obtained identifying the time value that maximizes each one of the equations shown in Table 2. In order to identify this value, the two partial differential equations resulting from the differentiation of each function were obtained. The system of these two algebraic equations was solved, considering each derivate equal to zero. Therefore, the value of the time was estimated for each temperature. 
Table 2. Equations of the Response Surface of moisture for each cultivar.

\begin{tabular}{|c|c|}
\hline Cultivar & $\begin{array}{l}\text { Equations } \\
\end{array}$ \\
\hline BRS CAUE & $M=21.7858+2.9101^{\star} x+0.7511^{\star} y-0.0657^{\star} x^{2}+0.0296^{\star} x^{\star} y-0.0106^{\star} y^{2}$ \\
\hline BRS BRAU & $M=27.4584+2.7514^{\star} x+0.3270^{\star} y-0.0644^{*} x^{2}+0.0341^{\star} x^{\star} y-0.0025^{\star} y^{2}$ \\
\hline BRS BOREMA & $M=17.2365+3.2859^{\star} x+1.8778^{\star} y-0.0733^{\star} x^{2}+0.0223^{\star} x^{\star} y-0.0358^{\star} y^{2}$ \\
\hline BRS 195 & $M=23.6867+2.9076^{\star} x+0.9230^{\star} y-0.0646^{\star} x^{2}+0.0376^{\star} x^{\star} y-0.0148^{\star} y^{2}$ \\
\hline BRS 225 & $M=20.3655+2.8244^{\star} x+1.0880^{\star} y-0.0659^{\star} x^{2}+0.0358^{\star} x^{\star} y-0.0167^{\star} y^{2}$ \\
\hline
\end{tabular}

$\mathrm{M}=$ Moisture (dry basis), $\mathrm{x}=$ time (hours), $\mathrm{y}=$ temperature $\left({ }^{\circ} \mathrm{C}\right)$.

Table 3. Optimization of hydration time calculated from the equations of the Response Surface.

\begin{tabular}{cllllll}
\hline Cultivar & \multicolumn{5}{c}{ Hydration Time for moisture equilibrium (h) } \\
\hline Temperature & $35{ }^{\circ} \mathrm{C}$ & $30{ }^{\circ} \mathrm{C}$ & $25^{\circ} \mathrm{C}$ & $20^{\circ} \mathrm{C}$ & $15^{\circ} \mathrm{C}$ & $10^{\circ} \mathrm{C}$ \\
\hline BRS CAUE & 30.03 & 30.03 & 27.78 & 26.65 & 26.53 & 24.40 \\
BRS BRAU & 30.63 & 29.30 & 27.98 & 25.65 & 25.33 & 24.70 \\
BRS BOREMA & 27.74 & 26.98 & 26.22 & 28.46 & 26.83 & 25.93 \\
BRS 195 & 32.69 & 31.23 & 29.78 & 26.86 & 25.41 \\
BRS 225 & 30.94 & 29.58 & 28.22 & 26.79 & 25.58 & 24.38 \\
Average & 30.41 & 29.42 & 28.00 & & & \\
\hline
\end{tabular}

Two important aspects observed are related to the time consumed and the equilibrium moisture attained during hydration. For example, in Table 3, the grains take an average of 30.41 hours to stabilize the value of moisture of $94.38 \%$ at $35^{\circ} \mathrm{C}$, while at $10^{\circ} \mathrm{C}$, it takes 24.38 hours to reach moisture content of $75.43 \%$. It is also observed that the moisture level reached also increases with increasing temperature, registering an average increase of approximately $19 \%$ moisture content on a dry basis by comparing the values obtained at 10 and $35^{\circ} \mathrm{C}$.

The Peleg model, with parameters $K_{1}$ and $K_{2}$, was used in the present study. These parameters were obtained from the linearization of the model provided by Equation 2, and their values are shown in Table 4. Figure 1 shows the experimental data and the prediction of the models for all temperatures tested. The coefficients of determination $\left(\mathrm{r}^{2}\right)$ shown in Table 4 indicate the quality of fit of the model to experimental data. The values of $\mathrm{r}^{2}$ ranged from 0.955 to 0.994 , confirming the suitability of the equation for describing the kinetics of water uptake by barley grains when the influence of temperature variation is investigated. The Peleg model was found to be adequate to describe the kinetics of hydration of barley cultivars in the present study. Cozzolino, Roumeliotis and Eglinton (2013) stated that the Peleg equation was applied to the curvilinear segment of the water absorption data. The data showed that differences in water result from the different barley cultivars used.

Studies by Sopade and Obekpa (1990) and Sopade, Ajisegiri and Badau (1992) showed that $K_{1}$ is a function of temperature and could be likened to a diffusion coefficient, and $\mathrm{K}_{2}$ is a characteristic sorption parameter of the material studied, with no significant temperature dependence. The Peleg constant $\mathrm{K}_{1}$ was found to be inversely proportional to temperature, showing a decreasing trend with increasing temperature. Several author reported decreasing $K_{1}$ values, namely Peleg (1988), Sopade, Ajisegiri and Badau (1992); Abu-Ghannam and McKenna (1997), Maskan (2002), Pan and Tangratanavalee (2003), and
Resio, Aguerre and Suarez (2006) for milk powder and rice; maize, millet and sorghum; red kidney beans; wheat; soybeans, and amaranth grain, respectively.

$\mathrm{K}_{2}$ also showed a decreasing behaviour with increasing temperature. This trend was also found in studies by Resio, Aguerre and Suarez (2006), who studied the kinetics of hydration of amaranth grain, and Pan and Tangratanavalee (2003) and evaluated the hydration of soybeans. According to these authors, when the equilibrium moisture content does not change with temperature, $\mathrm{K}_{2}$ is a temperature-independent variable; but when there is loss of solids and variation in the equilibrium moisture content during the hydration process, $\mathrm{K}_{2}$ becomes temperature-dependent and its values begin to decrease with increasing temperature.

Table 4 also shows the solid loss for each cultivar at different temperatures. The lowest average loss was $28.60 \%$ at $10{ }^{\circ} \mathrm{C}$. The loss of solid material to the liquid phase was also found to increase with increasing temperature. For the temperatures from $10{ }^{\circ} \mathrm{C}$ to $35^{\circ} \mathrm{C}$, an increasing average of $6.86 \%$ was observed in all cultivars. This difference represents an increase in solid loss by $25.32 \%$ related to the value recorded at $10^{\circ} \mathrm{C}$. In these experiments, $\mathrm{K}_{2}$ decreased with increasing temperature, probably due to loss of solids, which increased resistance to water transfer.

According to Sayar, Turhan and Gunasekaran (2001), the rate of water sorption can be explained by the diffusion phenomenon. In the hydration process, water content increases in the direction of the driving force. With the decrease of the driving force, the soluble solids offer resistance to water transfer. Water absorption capacity depends on the cell wall structure, grain composition and compactness of the seed cells.

The values of the initial absorption rate $\left(\mathrm{R}_{0}\right)$ are showed in Table 4 . The value of $K_{1}$ decreased with increasing temperature between 10 and $35^{\circ} \mathrm{C}$. Water absorption rate was found to increase with increasing temperature. Cultivar BRS BRAU 
Table 4. Parameters of Peleg's equation for the five barley cultivars.

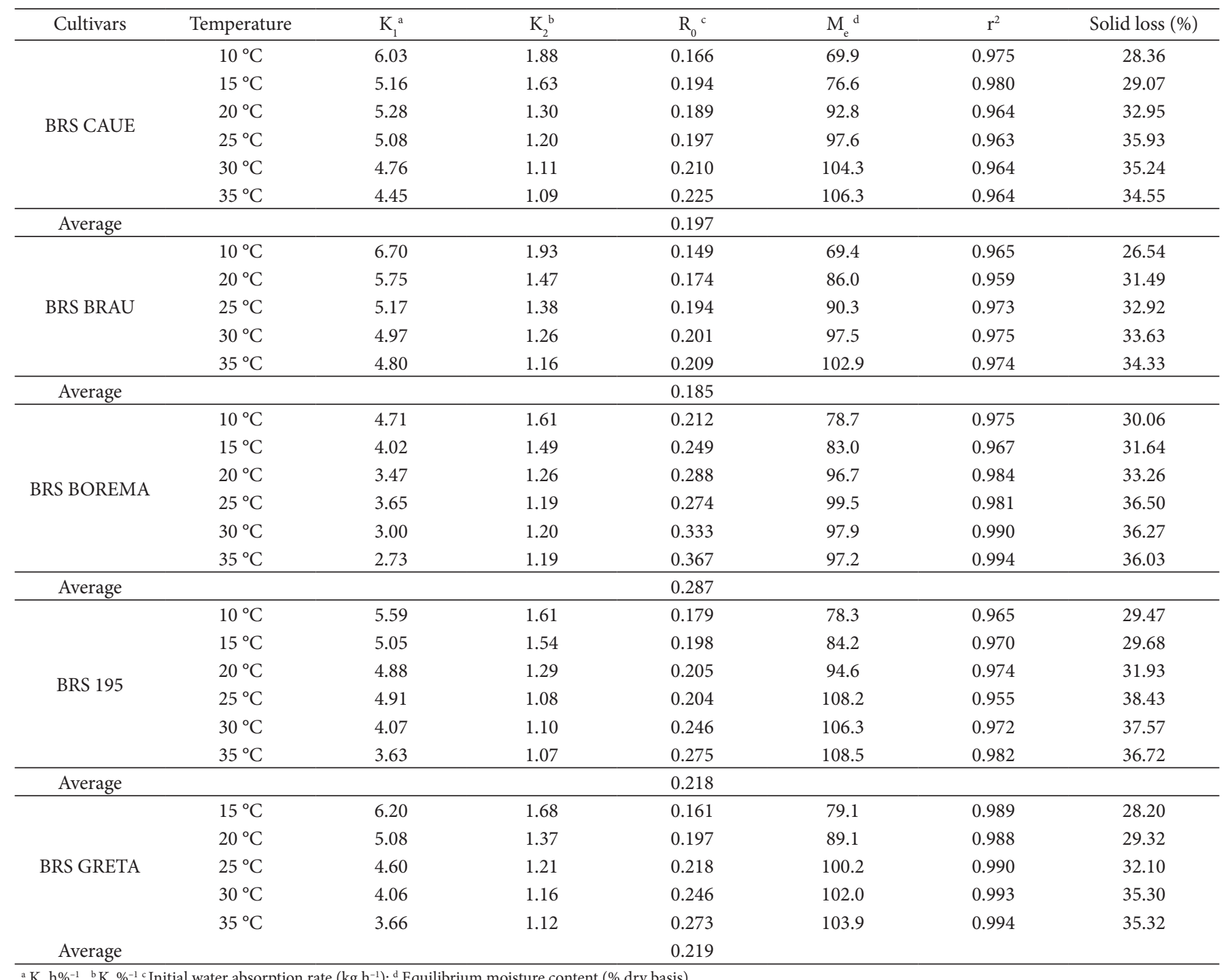

${ }^{a} \mathrm{~K}_{1} \mathrm{~h} \%^{-1},{ }^{\mathrm{b}} \mathrm{K}_{2} \%^{-1 \mathrm{c}}$ Initial water absorption rate (kg.h $\left.{ }^{-1}\right) ;{ }^{\mathrm{d}}$ Equilibrium moisture content (\% dry basis).

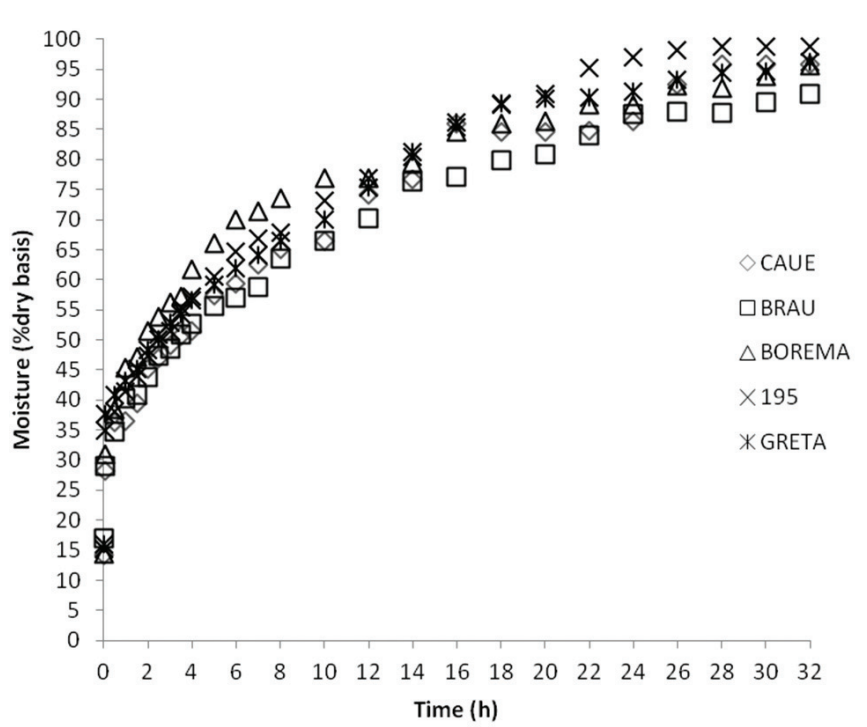

Figure 2. Hydration isotherm of five cultivars at temperature $30^{\circ} \mathrm{C}$. showed the lowest value of $\mathrm{R}_{0}\left(0.149 \mathrm{~kg} \cdot \mathrm{h}^{-1}\right.$ at $\left.10^{\circ} \mathrm{C}\right)$, and $\mathrm{BRS}$ BOREMA had the highest value of $\mathrm{R}_{0}\left(0.367 \mathrm{~kg} \cdot \mathrm{h}^{-1}\right.$ at $\left.35^{\circ} \mathrm{C}\right)$. Cultivar BRS BOREMA exhibited the highest average water absorption rate $\left(0.287 \mathrm{~kg} \cdot \mathrm{h}^{-1}\right)$, and BRS BRAU showed the lowest value $\left(0.196 \mathrm{~kg} \cdot \mathrm{h}^{-1}\right)$.

The final equilibrium moisture $\left(M_{e}\right)$ showed in Table 4 is different for each temperature. It can also be observed that the higher the hydration temperature, the greater the equilibrium moisture. Cultivar BRS BRAU had the lowest value of $\mathrm{M}_{e}: 69.4 \%$ (dry basis) at $10^{\circ} \mathrm{C}$, and BRS 195 showed the highest value: $108.5 \%$ (dry basis) at $35^{\circ} \mathrm{C}$. Resio, Aguerre and Suarez (2006) also observed that $M_{e}$ increased with increasing temperature during the hydration of amaranth grain. Arrhenius equation was used for the evaluation of the temperature dependence of $\mathrm{K}_{1}$. The activation energy is related to the slope of the straight line and therefore represents the influence of temperature on $\mathrm{K}_{1}$. Table 5 shows the activation energy obtained by linear regression, the hydration rate constant at the reference temperature $\left(\mathrm{K}_{\mathrm{ref}}\right)$, and 
Table 5. Parameters of Arrhenius equation for water absorption during barley hydration* and thermodynamic parameters of the hydration of barley cultivars.

\begin{tabular}{|c|c|c|c|c|c|c|c|}
\hline Cultivar & Temperature $\left({ }^{\circ} \mathrm{C}\right)$ & $\mathrm{Ea}(\mathrm{kcal} / \mathrm{mol})$ & $\mathrm{K}_{\mathrm{ref}}$ & $\mathrm{r}^{2}$ & $\Delta \mathrm{H}^{*}(\mathrm{kcal} / \mathrm{mol})$ & $\Delta \mathrm{S}^{*}(\mathrm{kcal} / \mathrm{mol} \mathrm{K})$ & $\Delta \mathrm{G}^{\star}(\mathrm{kcal} / \mathrm{mol})$ \\
\hline \multirow{6}{*}{ BRS CAUE } & 10 & \multirow{6}{*}{123.9} & \multirow{6}{*}{0.244} & \multirow{6}{*}{0.856} & -556.26 & -61.24 & 16805.23 \\
\hline & 15 & & & & -566.19 & -61.27 & 17111.51 \\
\hline & 20 & & & & -576.13 & -61.31 & 17417.97 \\
\hline & 25 & & & & -586.06 & -61.34 & 17724.60 \\
\hline & 30 & & & & -596.00 & -61.38 & 18031.39 \\
\hline & 35 & & & & -605.93 & -61.41 & 18338.35 \\
\hline \multirow{5}{*}{ BRS BRAU } & 10 & \multirow{5}{*}{158.1} & \multirow{5}{*}{0.228} & \multirow{5}{*}{0.938} & -553.61 & -61.37 & 16823.07 \\
\hline & 20 & & & & -573.48 & -61.44 & 17437.11 \\
\hline & 25 & & & & -583.41 & -61.47 & 17744.39 \\
\hline & 30 & & & & -593.35 & -61.50 & 18051.83 \\
\hline & 35 & & & & -603.28 & -61.54 & 18359.43 \\
\hline \multirow{6}{*}{ BRS BOREMA } & 10 & \multirow{6}{*}{238.8} & \multirow{6}{*}{0.398} & \multirow{6}{*}{0.864} & -549.69 & -60.26 & 16514.77 \\
\hline & 15 & & & & -559.62 & -60.30 & 16816.18 \\
\hline & 20 & & & & -569.56 & -60.33 & 17117.76 \\
\hline & 25 & & & & -579.49 & -60.37 & 17419.51 \\
\hline & 30 & & & & -589.43 & -60.40 & 17721.43 \\
\hline & 35 & & & & -599.37 & -60.43 & 18023.51 \\
\hline \multirow{6}{*}{ BRS 195} & 10 & \multirow{6}{*}{172.2} & \multirow{6}{*}{0.276} & \multirow{6}{*}{0.698} & -553.50 & -60.99 & 16737.97 \\
\hline & 15 & & & & -563.43 & -61.03 & 17043.02 \\
\hline & 20 & & & & -573.37 & -61.06 & 17348.25 \\
\hline & 25 & & & & -583.30 & -61.10 & 17653.64 \\
\hline & 30 & & & & -593.24 & -61.13 & 17959.20 \\
\hline & 35 & & & & -603.17 & -61.16 & 18264.92 \\
\hline \multirow{5}{*}{ BRS GRETA } & 15 & \multirow{5}{*}{282.6} & \multirow{5}{*}{0.326} & \multirow{5}{*}{0.950} & -557.12 & -60.70 & 16954.60 \\
\hline & 20 & & & & -567.05 & -60.73 & 17258.18 \\
\hline & 25 & & & & -576.99 & -60.77 & 17561.94 \\
\hline & 30 & & & & -586.92 & -60.80 & 17865.85 \\
\hline & 35 & & & & -596.86 & -60.83 & 18169.93 \\
\hline
\end{tabular}

${ }^{\star} \mathrm{T}_{\text {ref }}=$ reference temperature $(295.75 \mathrm{~K}) ; \mathrm{Ea}=$ activation energy; $\mathrm{K}_{\text {ref }}=$ hydration rate constant at the reference temperature; $\mathrm{r}^{2}=$ coefficient of determination.

the coefficient of determination $\mathrm{r}^{2}$. The values of $\mathrm{E}_{\mathrm{a}}$ obtained for the cultivars BRS CAUE and BRS BRAU, (respectively $123.9 \mathrm{kcal} / \mathrm{mol}$, and $158.1 \mathrm{kcal} / \mathrm{mol}$ ) were significantly lower than those of the cultivars BRS GRETA, BRS BOREMA and BRS $195(282.6 \mathrm{kcal} / \mathrm{mol}, 238.8 \mathrm{kcal} / \mathrm{mol}$ and $172.2 \mathrm{kcal} /$ mol, respectively). The lower value of $\mathrm{Ea}$ and the negatives values of entropy indicate that the seeds were more thermally stable and hydration changes was less influenced by temperature (JIDEANI; MPOTOKWANA, 2009). This result suggests that the rate of water absorption of the cultivars BRS CAUE and BRS BRAU are higher than that of the other cultivars and also that these cultivars get the equilibrium faster than the others, what can be observed in Figure 2. The higher values of Ea indicate that the seeds experience a large change and hydration was more influenced by temperature. According to Hsu (1983b), the activation energy is lower at high water contents, indicating that diffusion tends to be more temperature sensitive at low moisture contents (at the beginning of absorption) than it is at high water contents (toward the end of absorption).

The activation energy is a function of the grain composition; furthermore, it should be expected the occurrence of some effects of temperature and water content on diffusivity.

\subsection{Thermodynamic considerations}

Enthalpy is the heat released by hydration at constant pressure. It refers to the binding energy, intermolecular forces developed between the solvent, and the adsorbent surface and between the solvent and adsorbed molecules. The nature, homogeneity, and heterogeneity of the adsorbent surface can be characterized by the plot of the "heat curves" representing the evolution of isosteric heat of sorption versus solvent ratio. Enthalpy change provides a measure of the energy variations occurring on mixing water molecules with sorbent during the hydration process (OULAHNA et al., 2012). The values of enthalpy $\left(\Delta \mathrm{H}^{\star}\right)$ in Table 5 were negative for all cultivars, indicating that barley hydration is associated with exothermic (energetically favorable) transformations. The values of enthalpy differed between themselves $(\mathrm{p} \leq 0.05)$. Jideani and Mpotokwana (2009) also verified negative values of enthalpy in the hydration of Bambara seeds.

Entropy $(\Delta S)$ defines the degree of order of the water-sorbent system and helps to understand processes such as dissolution, crystallization, and swelling (MCMINN; AL-MUHTASSIB; MAGEE, 2003). Entropy is related to degrees of freedom of the adsorbent; it is a measurement of the disorder of the system. In accordance with the second law of thermodynamics, the 
phenomena are reversible if the entropy variation equals zero. In this study, entropy values were negative and were similar for all cultivars, with no significant difference $(\mathrm{p}>0.05)$.

Gibbs free energy is the driving force at constant temperature and pressure. Changes in free energy are generally coupled with enthalpy and entropy changes. The sign of $\Delta \mathrm{G}$ informs about the spontaneity of the reaction. If $\Delta \mathrm{G}<0$, the reaction is spontaneous (OULAHNA et al., 2012). In this study, positive values of $\Delta \mathrm{G}$ were obtained, showing that the process was not spontaneous. A significant difference $(\mathrm{p} \leq 0.05)$ was found for the cultivars at different temperatures. The $\Delta \mathrm{G}^{*}$ increased with increasing temperature was observed, indicating that hydration was influenced by temperature. However, the low values of $E_{a}$ and the negative values of entropy found for the cultivars BRS CAUE and BRS BRAU indicate that these cultivars are more thermally stable and for the changes during hydration are less temperature dependent.

\section{Conclusions}

Hydration temperature and time had significant influence $(p \leq 0.05)$ on the hydration kinetics of barley cultivars. The kinetics of hydration determined the time in hours required for the stabilization of the moisture into the grain; it was observed that the higher temperature, the longer the stabilization time required. Peleg model was adequate to describe the hydration of these cultivars at temperatures of 10 to $35^{\circ} \mathrm{C}$. Coefficients of determination indicated a good fit of Peleg model to the experimental data. The parameters $\mathrm{K}_{1}$ and $\mathrm{K}_{2}$ decreased with increasing temperature. The initial absorption rate $\left(\mathrm{R}_{0}\right)$ increased, and the amount of absorbed water increased with increasing temperature. Equilibrium moisture content $\left(\mathrm{M}_{\mathrm{e}}\right)$ increased with increasing temperature. Activation energy was lower for the cultivars BRS CAUE and BRS BRAU, indicating that the rate of water absorption of these cultivars is faster compared with that of the other cultivars with higher activation energy. Enthalpy and entropy values were negative, and Gibbs free energy was positive for all cultivars, with a significant effect $(\mathrm{p} \leq 0.05)$ of the time/temperature combination.

\section{Nomenclature}

\footnotetext{
$\mathrm{M}$ moisture content (\% dry basis)

$\mathrm{M}_{\mathrm{w}}$ mass of water present in the grain $(\mathrm{kg})$

$M_{d}$ mass of dry sample in the grain $(\mathrm{kg})$

$\mathrm{M}_{0}$ initial moisture content (\% dry basis)

t soaking time $(\mathrm{h})$

$\mathrm{K}_{1}$ Peleg rate constant $\left(\mathrm{h} \%^{-1}\right)$

$\mathrm{K}_{2}$ Peleg capacity constant $\left(\%^{-1}\right)$

$\mathrm{R}$ rate of sorption $\left(\mathrm{kg} \cdot \mathrm{h}^{-1}\right)$

$\mathrm{R}_{0}$ initial water sorption rate $\left(\mathrm{kg} \cdot \mathrm{h}^{-1}\right)$

$\mathrm{M}_{\mathrm{e}}$ equilibrium moisture content (\% dry basis)

$\mathrm{K}_{\text {ref }}$ refers to the hydration constant $\left(\mathrm{kg} . \mathrm{h}^{-1}\right)$

$\mathrm{T}_{\text {ref }}$ reference temperature $(\mathrm{K})$

$\mathrm{r}^{2}$ coefficient of determination

$\mathrm{E}_{\mathrm{a}}$ activation energy $((\mathrm{kcal} / \mathrm{mol})$

$\mathrm{R}$ universal gas constant $\left(\mathrm{J} \mathrm{mol}^{-1} \mathrm{~K}^{-1}\right)$

$\Delta \mathrm{H}^{*}$ enthalpy $((\mathrm{kcal} / \mathrm{mol}))$
}

$\Delta \mathrm{S}^{*}$ entropy $(\mathrm{kcal} / \mathrm{molK})$

$\Delta \mathrm{G}^{*}$ Gibbs free energy $(\mathrm{kcal} / \mathrm{mol})$

$\mathrm{k}_{\mathrm{b}}$ Boltzmann's constant (J.K.-1)

$\mathrm{h}_{\mathrm{p}}$ Planck's constant (J.s)

$\mathrm{T}$ absolute temperature (K)

\section{References}

ABU-GHANNAM, N.; MCKENNA, B. Hydration kinetics of red kidney beans (Phaseolus Vulgaris L.). Journal of Food Science, v. 62, n. 3, p. 520-523, 1997. http://dx.doi.org/10.1111/j.1365-2621.1997. tb04420.x

AMAN, P.; NEWMAN, C. W. Chemical composition of some different types of barley grown in Montana, U.S.A. Journal of Cereal Science, v. 4, n. 2, p. 133-141, 1987. http://dx.doi.org/10.1016/ S0733-5210(86)80016-9

ANDERSSON, A. A. M. et al. Chemical composition and microstructure of two naked waxy barleys. Journal of Cereal Science, v. 30, n. 2, p. 183-191, 1999. http://dx.doi.org/10.1006/jcrs.1999.0267

ASSOCIATION OF OFFICIAL ANALYTICAL CHEMISTS - AOAC. Official methods of analysis of AOAC. 16 ed. Arlington: AOAC, v. 2, 1995.

BAIK, B. K.; ULLRICH, S.E. Barley for food: characteristics, improvement and renewed interest. Journal of Cereal Science, v. 48, n. 2, p. 233-242, 2008. http://dx.doi.org/10.1016/j.jcs.2008.02.002

BARREIRO, J. A.; FERNÁNDEZ, S.; SANDOVAL, A. J. Water sorption characteristics of six row barley malt (Hordeum vulgare). Lebensmittel-Wissenschaft und -Technologie, v. 36, n. 1, p. 3742, 2003

COUTINHO, M. R. et al. Modelagem e validação da hidratação de grãos de soja. Ciência e Tecnologia de Alimentos, v. 25, n. 3, p. 603610, 2005. http://dx.doi.org/10.1590/S0101-20612005000300034

COUTINHO, M. R. et al. Novo modelo de parâmetros concentrados aplicado à hidratação de grãos. Ciência e Tecnologia de Alimentos, v. 27 , n. 3, p. 451-455, 2007. http://dx.doi.org/10.1590/S010120612007000300005

COZZOLINO, D.; ROUMELIOTIS. S.; EGLINTON, J. Monitoring water uptake in whole barley (Hordeum vulgare L.) grain during steeping using near infrared reflectance spectroscopy. Journal of Food Engineering, v. 114, n. 4, p. 545-549, 2013. http://dx.doi. org/10.1016/j.jfoodeng.2012.09.010

FOOD AND AGRICULTURE ORGANIZATION - FAO. 2007. Disponível em: <ftp://ftp.fao.org/docrep/fao/012/i1003e/i1003e00. pdf $>$. Accesso em: 20 ago. 2013.

GEANKOPLIS, C. J. Transport Processes: Momentum, Heat and Mass. (Allyn and Bacon series in engineering). Boston: Allyn \& Bacon, 350 p., 1983.

GOWEN, A. et al. Influence of pre-blanching on the water absorption kinetics of soybeans. Journal of Food Engineering, v. 78, n. 3, p. 965-971, 2007. http://dx.doi.org/10.1016/j.jfoodeng.2005.12.009

GRUWEL, M. H. et al. A magnetic resonance study of water uptake in whole barley Kernels. International Journal of Food Science and Technology, v. 36, n. 2, p.161-168, 2001. http://dx.doi.org/10.1046/ j.1365-2621.2001.00445.x

HSU, K. H. A diffusion model with a concentration-dependent diffusion coefficient for describing water movement in legumes during soaking. Journal of Food Science, v. 48, n. 2, p. 618-622, 1983a. http://dx.doi.org/10.1111/j.1365-2621.1983.tb10803.x 
HSU, K. H. Effect of temperature on water diffusion in soybean. Journal of Food Science, v. 48, n. 4, p. 1364-1365, 1983b. http://dx.doi. org/10.1111/j.1365-2621.1983.tb09236.x

HUNG, T. V. et al. Water absorption in chickpea and field pea cultivars using the Peleg model. Journal of Food Science, v. 58, n. 4, p. 848852, 1993. http://dx.doi.org/10.1111/j.1365-2621.1993.tb09374.x

IZYDORCZYK, M. S. et al. Variation in total and soluble b-glucan content in hulless barley: effects of thermal, physical, and enzymic treatments. Journal of Agricultural and Food Chemistry, v. 48, n. 4, p. 982-989, 2000. PMid:10775338. http://dx.doi.org/10.1021/ jf991102f

JIDEANI, V. A.; MPOTOKWANA, S. M. Modeling of water absorption of Botswana bambara varieties using Peleg's equation. Journal of Food Engineering, v. 92, n. 2, p. 182-188, 2009. http://dx.doi. org/10.1016/j.jfoodeng.2008.10.040

JIDEANI, V. A. et al. Mathematical modeling of odor deterioration of millet (Pennisetum glaucum) dough (fura) as affected by time- temperature and product packaging parameters. Cereal Chemistry, v. 79, n. 5, p. 710-714, 2002. http://dx.doi.org/10.1094/ CCHEM.2002.79.5.710

KASHANINEJAD, M. et al. Study of hydration kinetics and density changes of rice (Tarom Mahali) during hydrothermal processing. Journal of Food Engineering, v. 79, p. 1383-1390, 2007. http:// dx.doi.org/10.1016/j.jfoodeng.2006.04.019

KON, S. Effect of soaking temperature on cooking and nutritional quality of beans. Journal of Food Science, v. 44, n. 5, p. 1329-1335, 1979. http://dx.doi.org/10.1111/j.1365-2621.1979.tb06432.x

MASKAN, M. Effect of maturation and processing on water uptake characteristics of Wheat. Journal of Food Engineering, v. 47, n. 1, p. 51-57, 2001. http://dx.doi.org/10.1016/S0260-8774(00)00099-6

MASKAN, M. Effect of processing on hydration kinetics of three wheat products of the same variety. Journal of Food Engineering, v. 52, n. 4, p. 337-341, 2002. http://dx.doi.org/10.1016/S02608774(01)00124-8

MAYOLLE, J. E. et al. Water diffusion and enzyme activities during malting of barley grains: A relationship assessment. Journal of Food Engineering, v. 109, n. 3, p. 358-365, 2012. http://dx.doi. org/10.1016/j.jfoodeng.2011.11.021

MCMinN, W. A. M.; AL-MUHTASSIB, A. H.; MAGEE, T. R. A. Enthalpy-entropy compensation in sorption phenomena of starch materials. Food Research International, v. 38, p. 505-510, 2003.

OMOTO, E. S. et al. Mathematical modeling and analysis of pea grains hydration. Ciência e Tecnologia de Alimentos, v. 29, n. 1, p. 12-18, 2009. http://dx.doi.org/10.1590/S0101-20612009000100003

OSCARSSON, M. et al. Chemical composition of barley samples focusing on dietary fiber components. Journal of Cereal Science, v. 24, n. 2, p. 161-170, 1996. http://dx.doi.org/10.1006/jcrs.1996.0049

OULAHNA, D. et al. Agglomeration of durum wheat semolina: Thermodynamic approaches for hydration properties measurements.
Journal of Food Engineering, v. 109, n. 3, p. 619-626, 2012. http:// dx.doi.org/10.1016/j.jfoodeng.2011.10.003

PAN, Z.; TANGRATANAVALEE, W. Characteristics of soybeans as affected by soaking conditions. Lebensmittel-Wissenschaft und -Technologie, v. 36, n. 1, p. 143-151, 2003.

PELEG, M. An empirical model for the description of moisture sorption curves. Journal of Food Science, v. 53, n. 4, p. 1216-1217, 1988. http://dx.doi.org/10.1111/j.1365-2621.1988.tb13565.x

QUAST, D. G.; DA SILVA, S. D. Temperature dependence of hydration rate and effect of hydration on the cooking rate of dry legumes. Journal of Food Science, v. 42, n. 5, p. 1299-1303, 1977. http:// dx.doi.org/10.1111/j.1365-2621.1977.tb14482.x

QUINDE, Z.; ULLRICH, S. E.; BAIK, B. K. Genotypic variation in colour and discolouration potential of barley-based food products. Cereal Chemistry, v. 81, n. 6, p. 752-758, 2004. http://dx.doi. org/10.1094/CCHEM.2004.81.6.752

RESIO, A. C.; AGUERRE, R. J.; SUAREZ, C. Hydration kinetics of amaranth grain. Journal of Food Engineering, v. 72, n. 3, p. $247-$ 253, 2006. http://dx.doi.org/10.1016/j.jfoodeng.2004.12.003

SÁNCHEZ, L. et al. Kinetic parameters for denaturation of bovine milk lactoferrin. Journal of Food Science, v. 57, n. 4, p. 873-879, 1992. http://dx.doi.org/10.1111/j.1365-2621.1992.tb14313.x

SAYAR, S.; TURHAN, M.; GUNASEKARAN, S. Analysis of chickpea soaking by simultaneous water transfer and water-starch reaction. Journal of Food Engineering, v. 50, n. 2, p. 91-98, 2001. http:// dx.doi.org/10.1016/S0260-8774(00)00196-5

SEYHAN-GÜRTAS, F.; AK, M. M.; EVRANUZ E. O. Water diffusion coefficients of selected legumes grown in Turkey as affected by temperature and variety. Journal of Agriculture and Forestry, v. 25, p. 297-304, 2001.

SHARMA, P.; GUJRAL, H. S.; ROSELL, C. M. Effects of roasting on barley b-glucan, thermal, textural and pasting properties. Journal of Cereal Science, v. 53, n. 1, p. 25-30, 2011. http://dx.doi. org/10.1016/j.jcs.2010.08.005

SOPADE, P. A.; AJISEGIRI, E. S.; BADAU, M. H. The use of Peleg's Equation to model water absorption in some cereal grains during soaking. Journal of Food Engineering, v. 15, n. 4, p. 269-283, 1992. http://dx.doi.org/10.1016/0260-8774(92)90010-4

SOPADE, P. A.; OBEKPA, J. A. Modelling water absorption in soybean, cowpea and peanuts at three temperatures using Peleg's equation. Journal of Food Science, v. 55, n. 4, p. 1084-1087, 1990. http:// dx.doi.org/10.1111/j.1365-2621.1990.tb01604.x

TANG, J.; SOKHANSANJ, S.; SOSULSKI, F. W. Moisture-absorption characteristics of Laird lentils and hard shell seeds. Cereal Chemistry, v. 71, n. 5, p. 423- 428, 1994.

WANG, H. L. et al. Hydration of whole soybeans affects solids losses and cooking quality. Journal of Food Science, v. 44, n. 5, p. 15101513, 1979. http://dx.doi.org/10.1111/j.1365-2621.1979.tb06474.x 